\title{
English Teachers' Challenges in The Implementation of 2013 Curriculum in Vocational High Schools of Agriculture in South Kalimantan
}

\author{
Muhammad Ali Usman ${ }^{1}$, Sintha Tresnadewi ${ }^{1}$ \\ ${ }^{1}$ English Language Teaching-Universitas Negeri Malang
}

\begin{tabular}{l}
\hline \hline ARTICLE INFO \\
\hline Article History: \\
Received : 01-11-2019 \\
Approved : 16-05-2020 \\
\hline
\end{tabular}

\section{Key Words:}

teachers' challenges;

2013 curriculum;

vocational high school

\begin{abstract}
Abstract: This study is intended to describe challenges faced by English teachers in the Vocational High Schools of Agriculture during the implementation of 2013 Curriculum. This study used descriptive qualitative research design which was conducted at two Vocational High Schools of Agriculture in South Kalimantan. The result was devided into five items based on the research questions. The first was challenges in designing lesson plan. The second was challenges in the lesson implementation. The third was challenges in the learning assessment. The fourth was challenges in the classroom management practice. The last finding dealt with the implementation of professional development strategy.
\end{abstract}

\begin{abstract}
Abstrak: Penelitian ini bertujuan untuk mendeskripsikan tantangan-tantangan yang dihadapi oleh guru bahasa Inggris di SMK Pertanian selama implementasi Kurikulum 2013. Penelitian ini menggunakan desain kualitatif deskriptif yang dilaksanakan pada dua SMK Pertanian di Kalimanta Selatan. Hasil dari penelitian ini dibagi menjadi lima al berdasarkan pertanyaan penelitian. Pertama, tantangan-tantangan dalam penyusunan RPP. Kedua, tantangan-tantangan di dalam pelaksanaan pembelajaran. Ketiga, tantangan dalam evaluasi pembelajaran. Keempat, tantangan-tantangan dalam melaksanakan praktik manajemen kelas. Kelima, berkaitan dengan pelaksanaan strategi pengembangan profesionalisme guru.
\end{abstract}

\section{Correspondence Address:}

Muhammad Ali Usman

Pendidikan Bahasa Inggris

Universitas Negeri Malang

Jalan Semarang 5 Malang

E-mail: usmanbjb@gmail.com

The Undang-Undang Republik Indonesia Nomor 20 Tahun 2003 tentang Sistem Pendidikan Nasional stated that curriculum is one of the main components of education. Since July 2013, Indonesia has launched national curriculum known as 2013 Curriculum and it revised in 2017. The emergence of the 2013 curriculum is the reaction regarding the fact that Indonesia is following the respective years of global world and its problematic issues (Nur \& Madkur, 2014). According Wamendikbud (2014), the 2013 Curriculum is aimed to result the Indonesian people who are productive, creative, innovative and affective through the integrated reinforcement of the students' attitude, skill and knowledge. It is the process-based curriculum in which it developed the personal experience in the learning process through the process of observing, questionning, associating, experimenting, creating and communicating activities to increase the students' creativity. The government believes that every learning process should be based on the Scientific Approach which covers those activities. In addition, the assessment of learning process should also support the students' creativity. In other words, the concern of this curriculum is to develop students' creativity through scientific approach.

In the Lampiran Permendikbud Nomor 22 Tahun 2016 tentang Standar Proses Pendidikan Dasar dan Menengah, the 2013 Curriculum focuses on the three dimensions for the teachers' field; they are lesson planning, lesson implementation and learning assessment. Meanwhile, classroom management is one important items, considered by the teachers, in the learning implementation. Learning designer, learning motivator, learning mediator and learning inspirator are the roles of the teachers in this curriculum (Nur \& Madkur, 2014). It can be concluded that 2013 Curriculum is tended to be less teacher-centered as it focuses more on student-centered.

Beside those dimensions, 2013 Curriculum implementation could not be separated from the teachers' professionalism. Since their responsibility is to implement this curriculum in order to make the students productive, creative, innovative and affective, Mulyasa (2017) explained that the teachers are demanded to design the effective and meaningful (fun) learning, organize learning, determine the suitable approach, decide effectively the procedure of learning and development of competence and set the successful criteria. Those responsibilities make the teachers' creativity as one of the success key in the 2013 
Curriculum implementation (Mulyasa, 2017). Consequently, the efforts to develop and increase their professionalism during the curriculum implementation such as training, seminars or workhops are also important to be considered.

Studies reveal various challenges faced by English teachers in the stage of implementation concerning the three dimensions of curriculum: lesson planning, lesson implementation and learning assessment as well as the classroom management. The teachers expressed that it is difficult to determine the subject materials, the authentic assessments instrument in designing the lesson plan as demanded by the curiculum (Firdaus, 2016); (Khasanah, 2015). In the dimension of teaching process, the teachers perceive that they just have limited time to conduct English teaching and learning activities (Noviawati, 2017). Meanwhile, in implementing scientific approach, the teachers seem to be dominant in the learning process (Ahmad, 2014) and do not apply this approach completely (Albana, 2016); (Khasanah, 2015); (Ekawati, 2017). This report indicates that they are lacking of knowledge about 2013 Curriculum itself and the scientific approach as a new approach implemented in teaching and learning English (Napratilora et al., 2019). In addition, (Yusuf, 2018)) concludes that the teachers' knowledge represents strongly the way teachers implement Scientific Approach in the classroom. In terms of learning assessment, most of studies reveal that it is difficult for the teachers to implement scientific assessment (Nur \& Madkur, 2014); (Khasanah, 2015); (Albana, 2016); (Firdaus, 2016); (Noviawati, 2017); (Ekawati, 2017) referring to the students' competences such as social and spiritual competences, knowledge competence and skill competence. The limitation of time for administering the assessment and the complexity of the items (Febry, 2017) as well as the quite large size of class (Ahmad, 2014) are the factors that make them difficult in implementing the authentic assessment. In the classroom management practice, Habibi et al. (2017) conduct a qualitative study that reveals the problems such as lack of knowledge among English teachers regarding the latest technology, lack of up-to-date school facilities, large number of students in each class, lack space in the classroom, less opportunity for the students to practice (because the classes were too big), and situational problems, i.e. crowding in some classes.

The obstacles or problems that occur in the lesson planning, lesson implementation and assessment as well as in the classroom management indicate that the investigation toward the teachers' challenges in implementing this 2013 Curriculum becomes important things to do. In addition to this, it is also important to investigate the teachers' efforts to overcome those challenges through a number of professional development strategies. It is a challenge for the researchers to explore it in depth to unveil the comprehensive data that document the challenges faced by the teachers in the curriculum implementation, as this data would give the valid or convincing description of the English teachers' competence and readiness to implement the 2013 Curriculum in terms of lesson planning, lesson implementation, learning assessment and classroom management. Therefore, the stakeholders enable to use the data as the basic condition to formulate the policy related to the implementation of 2013 Curriculum in all levels of education in Indonesia, including in the vocational education.

The government has launched the regulation in the Lampiran III Permendikbud Nomor 34 Tahun 2018 tentang Standar Kompetensi Lulusan SMK/MAK which covers the three dimensions in the process of teaching and learning; lesson planning, lesson implementation and learning assessment. However, there are less of studies investigate the teachers' challenges in the implementation of 2013 Curriculum dealing those dimensions in the SMK or Vocational High Schools. A study by Ekawati (2017) investigate teachers' problems in applying the 2013 curriculum at vocational high school in Tegal. Most of studies bear on to the implementation of this curriculum in the Junior High School (Nur \& Madkur, 2014); (Albana, 2016) and Senior High Schools (Firdaus, 2016); (Khasanah, 2015); (Ahmad, 2014); (Noviawati, 2017); (Febry, 2017); (Yusuf, 2018). Meanwhile, the challenges faced by the English teachers of Vocational High School in implementing the 2013 Curriculum may be various and different compared with other kind of schools as it is inline with the implementation of English for Specific Purposes (ESP) which is designed to meet the learners' needs (Hutchinson \& Waters, 1987). In this case, the needs refer to a number of expertises, say, enginering, agriculture, ITC, maritime, etc. It is also needed to provide the comprehensive data which document the English teachers' challenges in the vocational education. The three dimensions in 2013 Curriculum such as lesson planning, lesson implementation and assessment as well as classroom management become concern in its implementation in the secondary education levels including in the Vocational High Schools. However, there is only a study by Ekawati (2017) as the previous study which focus in the vocational high school level which cover those three dimensions. Meanwhile, Irawati (2016) in her case study investigates the Vocational High School English teachers' perspective on the 2013 Curriculum English materials. Her study tends to explore the aspect of English materials used in this curriculum rather than the dimensions of its implementation.

Considering the limited number of studies have been reviewed related to the English teachers' challenges in the implementation of 2013 Curriculum in the area of vocational education and the dimensions that should be covered, this present study was conducted to cover those area and dimensions. This study tried to inquire the challenges faced by the Vocational High School English teachers majoring in Agribusiness and Agrotechnology in the 2013 Curriculum implementation. Since there are 83 schools in the same major under the scope of Agricultural Ministry (Rusmono, 2018) and all of those schools have implemented 2013 Curriculum, hopefully, the result of this study will give the positive contribution in this major area. To deal with the dimensions of curriculum implementation, this present study focused on a number of aspects such as teachers' challenges in lesson planning, lesson implementation, learning assessment and classroom management as well as their efforts to conduct professional development strategies. The consideration is that those focuses include in the regulation of teaching and learning process implemented in the 2013 Curriculum (Lampiran Peraturan Menteri Pendidikan dan Kebudayaan Nomor 22 Tahun 2016 tentang Standar Proses Pendidikan Dasar dan Menengah). Thus, the present study is aimed to discover: 1) What 
are the challenges in the lesson planning faced by the Vocational High School of Agriculture English teachers?, 2) What are the challenges in the lesson implementation faced by the Vocational High School of Agriculture English teachers?, 3) What are the challenges in the learning assessment faced by the Vocational High School of Agriculture English teachers?, 4) What are the challenges in the classroom management faced by the Vocational High School of Agriculture English teachers?, 5)How do the Vocational High School of Agriculture English teachers conduct professional development strategies to overcome challenges in the 2013 Curriculum implementation?

\section{METHOD}

The focus of this study was to identify and describe the challenges in lesson planning, lesson implementation, learning assessment, classroom management practice and implementation of professional development strategies experienced by EFL vocational teachers. As this study relied as much as possible on the participants' views and situation being studied, a descriptive qualitative research design was implemented to discover the answers of the research questions. A descriptive qualitative research design is acceptable in obtaining data on behavioral and social phenomenon rather than experimental settings because this research design gives more emphasize on the experiences, meanings, and views of the participants (Lambert \& Lambert, 2012). Therefore, it was an appropriate design to obtain the aims of this study in which the challenges experienced by the teachers in the 2013 Curriculum implementation were explored.

This study was carried out in two Vocational High Schools of Agriculture in South Kalimantan which have been implementing 2013 Curriculum. They are SMK Pertanian Pembangunan Negeri Banjarbaru located in Kota Banjarbaru and SMK Pertanian Pembangunan Negeri Pelaihari located in Kabupaten Tanah Laut. There are various vocational study programs or expertises related to Agriculture in those schools such as Agribisnis Tanaman Pangan and Hortikultura, Agribisnis Tanaman Perkebunan, Agribisnis Pengolahan Hasil Pertanian, Agribisnis Ternak Ruminansia as well as Kesehatan and Reproduksi Hewan. Considering the nearness of location, the researcher determined to choose the research subjects from both those two vocational high schools. Since those vocational schools are geographically located in different kind of area such as urban, rural, mining and plantation, the students' family background are different.

The research subjects in this study were four English teachers who worked in those two vocational high schools. They were selected purposively based on their experience in teaching English in those schools during the implementation of 2013 Curriculum. Moreover, since there were no other English teachers in those schools, the researcher decided to involve all of them in this study.

Table 1. Background Information of the Research Subjects

\begin{tabular}{lcccc}
\hline \multicolumn{1}{c}{ Information } & \multicolumn{3}{c}{ Subjects } \\
\cline { 2 - 5 } & Teacher A & Teacher B & Teacher C & Teacher D \\
\hline Class level taught & X zand XI & XI and XII & X & XI and XII \\
Number of teaching times in a week & 18 hours & 24 hours & 12 hours & 20 hours \\
Experience in teaching English & 10 years & 4 years, 1 month & 3 years, 10 months & 10 years, 1 month \\
Gender & Female & Male & Female & Female \\
Background of education & ELT & ELT & Economic Accounting & ELT \\
\hline
\end{tabular}

The data obtained in this study was qualitative that it was containing the primary and supporting data. The primary data in this study was gained from the English teachers through questionnaires, interview and observation. Meanwhile, the supporting data was gained from the students, principles and relevant documents through interview and document analysis. The data and sources of data are described in the table 2 .

Table 2. Data and Sources of Data

\begin{tabular}{clll}
\hline No & \multicolumn{1}{c}{ Problems } & \multicolumn{1}{c}{ Data Types } & \multicolumn{1}{c}{ Source of Data } \\
\hline 1. & $\begin{array}{l}\text { Teachers' challenges in designing the lesson } \\
\text { planning }\end{array}$ & Written \& Spoken & $\begin{array}{l}\text { Teachers, Syllabus \& Lesson Plan } \\
\text { Teachers }\end{array}$ \\
2. & Teachers' challenges in lesson implementation & Written \& Spoken & $\begin{array}{l}\text { Students } \\
\text { Teachers } \\
\text { Teachers }\end{array}$ \\
3. & Teachers' challenges in learning assessment & Written \& Spoken & St, O \\
4. & Teachers' challenges in classroom management & Written \& Spoken & $\begin{array}{l}\text { Students } \\
\text { Teachers, Sertificates \& relevant } \\
\text { documents }\end{array}$ \\
5. & $\begin{array}{l}\text { Implementation of professional Development } \\
\text { Strategies }\end{array}$ & Written \& Spoken & I, O
\end{tabular}


The English teachers as the sources of primary data of this study were four English teachers of two Vocational High Schools in South Kalimantan. The data gained were qualitative related to their written and spoken responses as well as their practice in designing lesson plan, implementing the lesson plan, learning assessment and classroom management practice. Since each school has just two English teachers who teach tenth to twelfth grades, then all of them were involved to get the the primary data in this study. As one of supporting data sources, the students were involved in this study. They were the students to whom the teachers implement of 2013 Curriculum. The data obtained were qualitative related to their written and spoken responses in perceiving their teachers in terms of lesson implementation and classroom management practice. Another supporting data was also gained from the principals as the top leader of the schools in which the teachers work. The qualitative data that was explored was the institutions' role in developing their English teachers' professionalism related to the implementation of 2013 Curriculum. To confirm the data obtained from the teachers about lesson planning and their professional development strategies, document analysis was conducted regarding to the syllabus, lesson plan, certificates of training or workshop and other relevant documents such as teachers' portfolio or report of clasrroom action research.

This study employed four techniques of data collection. They were questionnaires distribution, interviews, classroom observation and document analysis. Thus, in this present study, the researcher employed four kinds of instruments to collect the data. They were questionnaire, interview guides, classroom observation sheet and document analysis sheet. The questionnaire used to collect the data in this study consistsed of a number of closed-ended questions. It explores respondents' background information, the challenges experienced by the respondents in developing lesson plan, in the lesson implementation, in the learning assessment, in the classroom management and their experience in conducting professional development strategies.

Semi-structured interview in form of open-ended questions were conducted in this study to clarify the information written by the subjects in the questionnaires. Audio recorder was used during the interview conducted. The first interview guide was employed for the interviewing the teachers related to the items or questions in the questionnaires. The questions were aimed to clarify and elaborate the information gained from the teachers' questionnaire. To confirm what the student perceive regarding the teachers' teaching practice in the classroom, the second interview guide was employed. The students interviewed were representatives of the class taught and recommended by the English teachers. The third interview guideline was employed to interview the principals of both vocational schools concerning the exploration toward the schools' roles in facilitating and supporting the English teachers to conduct the professional development strategies as they effort to enrich their understanding and to develop their competencies in the 2013 Curriculum implementation.

The observation was used to watch directly teachers' and students' behaviors and interactions in the classroom. In this study, observation was focused on the lesson implementation and classroom management practice. The content of observation sheet was related to the aspects of the teachers' questionnaires in terms of lesson implementation and classroom management to get the connection or consistency of what the teachers have stated in the questionnaires and what they do in the classroom (performance). Meanwhile, the document analysis was conducted to enrich the primary data obtained from the teachers. It was focused to confirm the data related to the lesson planning that consisted of syllabus and lesson plan prepared by the English teachers. Besides that, it was also focused on the relevant documents related to administering the professional development strategies by the teachers such as certificates, action research report and others.

The data gained from the instruments was analyzed in different way. The data resulted from the teachers' questionnaire was analyzed quantitatively since the items of questionnaire use closed-ended questions in the four Likert scale. The data resulted from interview, observation and document analysis was analyzed qualitatively. In this study, the researcher adapted the steps of qualitative analysis proposed by Creswell (2012). The steps started from preparing and organizing the data, reading or exploring and coding all data, representing the data and interpreting the data.

In order to reduce the researcher biases and prejudice, the procedure of triangulation was needed in this research. Triangulation can be defined as the use of two or more methods of data collection in the study of some aspect of human behavior (Cohen et al., 2007). In line, (Patton, 1999) defines it as use of multiple methods or data sources in qualitative research to develop a comprehensive understanding of phenomena. In this study, triangulation was conducted by crosschecking (comparing and contrasting) the data obtained from multiple techniques in the same investigated aspects with the purpose of presenting a comprehensive data. The researcher made the comparison between what he found in the observation, document analysis, students interview and principals' interview and what the teachers confessed in the teachers' interview. By doing this, the accuracy of the researchers' interpretation was expectedly gained.

\section{FINDINGS}

\section{The Vocational High School English Teachers' Challenges in the Lesson Planning}

The data of challenges in the lesson planning was collected based on Agricultural Vocational English teachers' experiences in designing their lesson plan. It was gained through questionnaires, interview and documents analysis. The result showed that among the items should be considered in designing lesson plan, there were three items that raised the problems faced by English teachers. The data was showed in the table 3. 
Table 3. The Data of English Teachers' Challenges in Designing Lesson Plan

\begin{tabular}{cllll}
\hline No & Research Problems & Source of Data & \multicolumn{1}{c}{ Instruments } & \multicolumn{1}{c}{ Data Findings } \\
\hline 1. $\begin{array}{l}\text { Teachers' challenges } \\
\text { in designing the } \\
\text { lesson planning }\end{array}$ & $\begin{array}{l}\text { English Teachers, } \\
\text { Syllabus \& } \\
\text { Lesson Plan }\end{array}$ & $\begin{array}{l}\text { Questionnaires, } \\
\text { Interview, Document } \\
\text { Analysis }\end{array}$ & $\begin{array}{l}\text { 1. } \\
\text { Teachers feel confused to review the syllabus of 2013 } \\
\text { Curriculum revision version since it is not as complete as } \\
\text { the before revision one. } \\
\text { Teachers feel difficult to decide the correct indicators } \\
\text { since they have less knowledge in developing KD into } \\
\text { indicators, meanwhile the different intake of students } \\
\text { make it to be more difficult. } \\
\text { Teachers could not cover all aspects of learning } \\
\text { assessment in the Lesson Plan since they realize that will } \\
\text { have limited time to conduct, meanwhile their students } \\
\text { have low intake or ability. }\end{array}$ \\
\hline
\end{tabular}

The problems in the lesson planning consisted of teachers' difficulties in reviewing syllabus, deciding indicators and determining kind of assessment. Based on the teachers' explanation for each of problems in this stage, determining indicators was the most difficult step for the teachers to do and it was followed by reviewing syllabus and determining learning assessment.

\section{The Vocational High School English Teachers' Challenges in the Lesson Implementation}

The data related to the challenges in the lesson implementation was collected referring to the Agricultural Vocational High School English teachers' experiences in implementing their lesson plan of 2013 Curriculum in the classroom. It was gained through questionnaires, interview and observation. The result showed that among the items should be considered in the lesson implementation covered pre activity, main activity and post activity based on the 2013 Curriculum, there were seven items that raised the problems faced by English teachers. The data was showed in the table 4 .

The problems in the lesson implementation consisted of teachers' difficulties in pre activities such as preparing and motivating students to learn and connecting the students' prior knowledge with the material being learnt. Meanwhile, the teachers' problems in the main activities covering their difficulties in applying scientific approach steps such as guiding the students in observing, questioning, associating and communicating. Furthermore, applying all steps of scientific approach in sequence in the teaching procedure was also difficult for all teachers even though it was not compulsory. Among all problems in the lesson implementation, the most challenges experienced by English teachers in the lesson implementation stage was organizing the steps of scientific approach in sequence way.

\section{The Vocational English Teachers' Challenges in the Learning Assessment}

The data related to the challenges in the learning assessment was collected referring to the Agricultural Vocational High School English teachers' experiences in conducting the learning assessment based on 2013 Curriculum in the classroom. It was gained through interview and observation. The result showed that among the items should be considered in the learning assessment activity, there was one item that raised the problems faced by English teachers. The data was showed in the table 5.

The problems in the learning assessment consisted of teachers' difficulty to cover all aspects of assessment in the 2013 Curriculum. The students' condition and limited time were the contributed factors that make the teachers difficult to cover all aspects of assessment in the area of students' knowledge and skill.

\section{The Vocational English Teachers' Challenges in the Classroom Management Practice}

The data related to the challenges in the classroom management was collected referring to the Agricultural Vocational High School English teachers' experiences in managing their classroom during the implementation of 2013 Curriculum. It was gained through questionnaires, interviews and observation. The result showed that among the items should be considered in the classroom management as the curriculum demand, there were three items that raised the problems faced by English teachers. The data was showed in the table 6. 
Table 4. The Data of English Teachers' Challenges in the Lesson Implementation

\begin{tabular}{|c|c|c|c|c|}
\hline No & Research Problems & Source of Data & Instruments & Data Findings \\
\hline 2. & $\begin{array}{l}\text { Teachers' challenges } \\
\text { in lesson } \\
\text { implementation }\end{array}$ & $\begin{array}{l}\text { English } \\
\text { Teachers, } \\
\text { Students }\end{array}$ & $\begin{array}{l}\text { Questionnaires, } \\
\text { Interview, } \\
\text { Observation }\end{array}$ & $\begin{array}{l}\text { 1. Teachers feel difficult to prepare and motivate the students for } \\
\text { learning in the pre activity since the students are so tired after } \\
\text { attending other lessons in the field before come to the English } \\
\text { lesson. } \\
\text { 2. Teachers feel difficult to connect the students' prior knowledge } \\
\text { with the material which will be learnt since the students have } \\
\text { various intake and background knowledge. } \\
\text { 3. Teachers face difficulty to guide the students in observing } \\
\text { stage since they have low vocabulary mastery and low } \\
\text { motivation to use their pocket dictionary, therefore they could } \\
\text { not identify text or other materials correctly. } \\
\text { Teachers feel difficulty to guide most of the students to ask the } \\
\text { questions in the questioning stage although they have been } \\
\text { encouraged to ask what they want to know to their English } \\
\text { teachers. } \\
\text { Teachers face difficulty to guide the students to conduct } \\
\text { associating stage since there are just little number of students } \\
\text { who can interprete or conclude the materials which is being } \\
\text { learnt correctly rather than the most of them. } \\
\text { Teachers feel difficulty to encourage all the students in order to } \\
\text { be involved in communicating their tasks or assignments since } \\
\text { there is there is little number of them are active while the rest } \\
\text { are passive, afraid or not confident. } \\
\text { The teachers could not conduct the Scientific Approach in } \\
\text { sequence way since they think that it should be adjusted to } \\
\text { kind of materials being learnt, students condition and time } \\
\text { management. }\end{array}$ \\
\hline
\end{tabular}

Table 5. The Data of English Teachers' Challenges in the Learning Assessment

\begin{tabular}{clllll}
\hline No & Research Problems & Source of Data & \multicolumn{1}{c}{ Instruments } & \multicolumn{2}{c}{ Data Findings } \\
\hline 3. & Teachers' challenges in & English & Questionnaire, & 1. Teachers could not cover all aspects of learning \\
& learning assessment & Teachers, & Interview, Observation & assessment in the 2013 Curriculum caused by the \\
& & & Students & & students condition and limited time.
\end{tabular}

Table 6. The Data of English Teachers' Challenges in the Classroom Management Practice

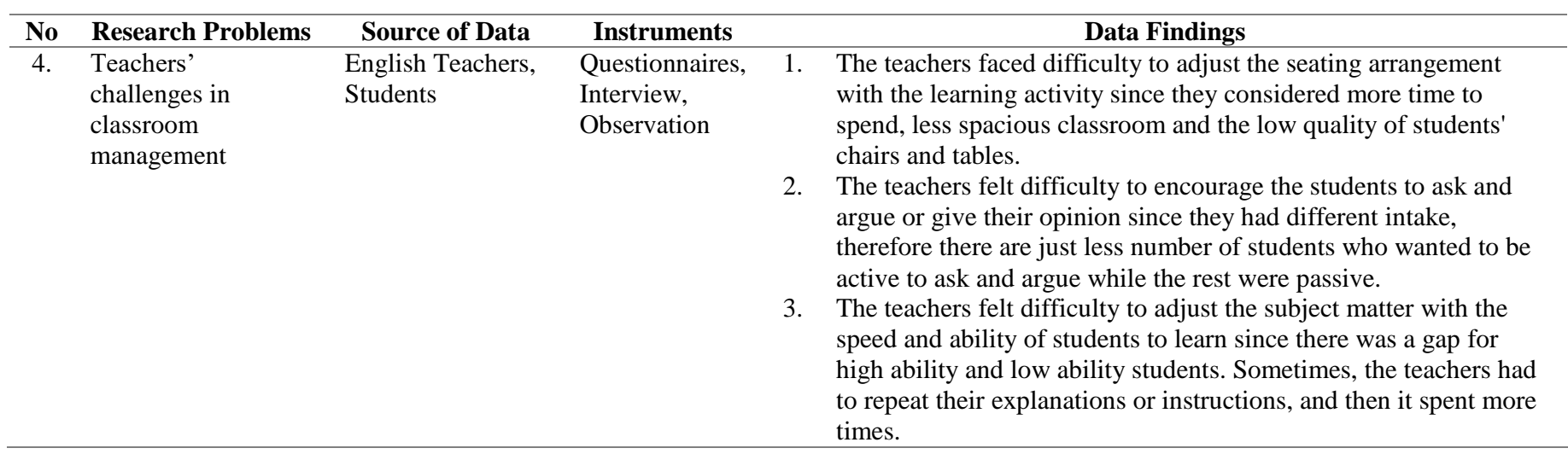

The problems in the classroom management practice consisting of teachers' difficulties in adjusting the seating arrangement with the learning activity, encouraging the students to ask and argue or give their opinion and adjusting the subject matter with the speed and ability of students to learn. Considering those three problems and the teachers' explanation related to each problem, encouraging the students to ask and argue or giving their opinion was the most difficult item for the teachers in classroom management practice. 


\section{The Professional Development Strategies Conducted by Vocational High School English Teachers}

The data related to the description of professional development strategies conducted by the teachers was collected from the teachers as the primary sources of data, the principals and relevant document as the supporting data. It was gained through questionnaires, interviews and reviewing the document. Generally, the result showed that all the principals felt that they had facilitated and supported their English teachers to conduct professional development strategies. Among the items of strategies should be considered in the teachers' professional development, there one item that describe the implementation of strategies and three items that described the challenges faced by English teachers. The data was showed in the table 7.

Table 7. The Data of Implementation of Professional Development Strategies Conducted by English Teachers

\begin{tabular}{|c|c|c|c|c|}
\hline No & Research Problems & Source of Data & Instruments & Data Findings \\
\hline 5. & $\begin{array}{l}\text { Description of } \\
\text { professional development } \\
\text { strategies implementation }\end{array}$ & $\begin{array}{l}\text { English } \\
\text { Teachers, } \\
\text { Principals, } \\
\text { Certificates }\end{array}$ & $\begin{array}{l}\text { Questionnaires, } \\
\text { Interview, Document } \\
\text { Analysis }\end{array}$ & $\begin{array}{l}\text { 1. Most of strategies conducted were teaching portfolio, in- } \\
\text { service training, and study group while the rest were } \\
\text { rarely or never conducted such as peer-coaching, } \\
\text { mentoring, team teaching and action research. } \\
\text { 2. The teachers got difficulty to conduct peer-coaching and } \\
\text { team teaching since they could not match their time with } \\
\text { their partner. } \\
\text { 3. Some teachers felt that they did not get support from } \\
\text { their school to attend the meeting of MGMP, especially } \\
\text { for financial support and administration. } \\
\text { The teachers felt difficulty to get the information access } \\
\text { about seminars or training that could increase their } \\
\text { knowledge and ability in teaching as the } 2013 \\
\text { Curriculum demands. Therefore, they had less number of } \\
\text { presence in the seminars or trainings. }\end{array}$ \\
\hline
\end{tabular}

Generally, the teachers conducted the professional development strategies. The fact showed that most of strategies conducted were teaching portfolio, in-service training, and study group while the rest were rarely or never conducted such as peer-coaching, mentoring, team teaching and action research. The problems faced by the teachers were difficulty to conduct peer-coaching and team teaching, difficulty to get support from the school for study group as MGMP, and difficulty to get information access about seminar, workshop, or training related to 2013 Curriculum.

\section{DISCUSSION}

\section{The Vocational High School English Teachers' Challenges in the Lesson Planning}

In this part, the researcher discussed and interpreted the findings in the lesson planning. As presented in the previous chapter, the English teachers' challenges in the lesson planning during the implementation of 2013 Curriculum in the Vocational High School of Agriculture consisted of three themes: reviewing syllabus, deciding the indicators and determining the learning assessment.

Concerning the challenge in reviewing syllabus as the initial stage of developing lesson plan, the teachers felt confused to review the syllabus of 2013 Curriculum revision 2017 version since its content was not as complete as the syllabus before revision. Considering the fact that there have not been the adequate syllabus of 2013 Curriculum revision 2017 version launched by the government, it was understandable that the teachers felt confused to use this revision version and preferred to use the syllabus of 2013 Curriculum before revision version since it was more complete in terms of its content.

The next challenge dealt with teachers' difficulty in formulating indicators since the lack of knowledge to formulate and the various students' background in English ability were the factors that trigger this difficulty. Mulyasa (2017) defined that indicator was the measurable and observable attitude that indicated the achievement of certain Basic Competence as references for learning assessment of each subject matter. In addition, indicators of competence achievement were formulated by using the operational verbs that were measurable and observable covering behavior, knowledge and skill (Menteri Pendidikan Nasional, 2007). Developing indicators needed the information of students' characteristics that were unique and various. Since they have various intelligence and learning style, the indicators should accommodate those varieties.

The last was the challenge in term of determining the learning assessment. Realizing the limited time to conduct assessment following the whole aspects in the 2013 Curriculum should be assessed, made the teachers did not cover all techniques of learning assessment in the lesson plan. The techniques should be implemented was observation, self-assessment, peer-assessment, journal, written test, oral test, tasks, performance, project and portfolio.

Those challenges in the stage of lesson planning in this study completed the problems faced by the teachers in preparing their lesson plan of 2013 Curriculum in the previous studies. As the studies revealed by Firdaus (2016) and Khasanah (2015), teachers got difficulty to determine the subject materials, the methods used and the instrument of authentic assessments in designing the lesson plan as demanded by the 2013 Curiculum. In addition, Widiati et al. (2018) in their study revealed that 
the teachers' difficulty was on how to design teaching and learning activities that are motivating to the students since their students generally lacked the motivation and ability to learn. In line with those findings, Ekawati (2017) in her study concluded that the teachers' problem in preparing lesson plan was caused by the teacher's readiness since they got difficulty in identifying and arranging learning objective, indicators, material, method of teaching, learning activities and evaluation. In short, the teachers' challenges in terms of syllabus review, formulating indicators and determining the techniques of learning assessment in this present study showed the fact that the teachers' understanding in the lesson planning needed to be increased.

\section{The Vocational High School English Teachers' Challenges in the Lesson Implementation}

Based on the findings in the stage of lesson implementation, there were seven challenges faced by the English teachers. Two of them appeared in the pre activity while the rest occurred in the main activity of the teaching-learning practice. The teachers' challenges in the pre activity dealt with the students' condition before learning English. As the curriculum demands, the teachers have to conduct several activities to prepare the students to learn such as preparation of students' spirituality and physique, motivation, connecting background knowledge and explaining the lesson objectives as well as the scope of material. Meanwhile, it could not be avoided in the vocational education that they have vocational subjects based on Peraturan Menteri Pendidikan dan Kebudayaan Nomor 70 tahun 2013 tentang Kerangka Dasar dan Struktur Kurikulum SMK/MAK which also required them to practice in the field, they got tired after that to attend other lessons including English. This condition sometimes made the English teachers difficult to conduct those pre activities, especially in the preparing and motivating the students to learn. Meanwhile, Anni \& Rifa'i (2009) stated that motivation was not only the important factor for students to learn, but also it supported the learning process and result.

The teachers' challenges in the pre activity also appeared when they had to connect the students' prior knowledge with the materials that was being learnt since they had various intake and background knowledge. Students' intake was the prior knowledge in a certain subjects and could directly or indirectly influence the process of learning (Setyawan, 2012). Moreover, Schulman (1999) in Hasan et al. (2017) pointed out that the terms background knowledge and prior knowledge are generally used interchangeably. In addition, any new learning must, in some fashion, connect with what learners already know, learners construct their sense of the world by applying their old understanding to new experiences and ideas. Therefore, connecting this prior knowledge with what the students were learning was very important to do by the English teachers although the students had different intake and background knowledge.

Referring to the implementation of scientific approach in the main activity, the challenges occurred were in the stage of observing, questioning, associating and communicating. Observing activity was aimed to develop student's curiosity, to create meaningful learning process and help students acquire knowledge (Brown, 2000). In this activity, what the Vocational School English teachers conducted was actually in line with the concept by Checkovich \& Sterling (2001) in which the teachers guided the students to observe objects, events, phenomena, concepts and procedures by using all of their senses to see, listen, read and watch, and integrate it with the learning material.

However, students' low mastery of vocabulary and low motivation to find the meaning of the words or sentences they observed were the challenges faced by the teachers in this observing stage. Vocabulary mastery in language learning was very important since it was the key to understand what students heard and read and to communicate successfully with other people (Shoebottom, 2007 in Sharafi-Nejad et al., 2014). Meanwhile, students' motivation in the process of learning was also important to be considered by the teachers due to the fact that it led individuals to take action to achieve a goal or to fulfill a need or expectation (Gopalan et al., 2017).

The challenge in the questioning stage related to the teachers' difficulty in guiding the students to ask the questions related to what they have observed although they have been encouraged to ask what they want to know to their English teachers. The teachers' effort in this case was in line with the purpose of questioning stage in which the students were required to have a critical thinking to evoke high level of thinking questions (Ratnaningsih, 2017). Moreover, they could show their active participation in the learning process. Therefore, the teachers had to facilitate the students with scaffolding to stimulate and encourage the students to ask the questions (Menteri Pendidikan Nasional, 2013). The problem rose then, that most of students did not response to ask the questions because they confused or doubt what should be asked to their teachers since they felt that they have no questions to be asked. The difficulty to tell their questions in English was also the students' problem that made them unwilling to ask.

In the associating stage, the information or data that have been collected from the previous activity (observing and experimenting) must be analyzed to draw conclusions. However, the problem was that the teachers got difficulty to involve all students to be active since there was just little number of students who could interpret or conclude the materials which were being learnt correctly rather than the most of them. Lack of vocabulary among most of the students could be the main factor that caused this problem. 
The next challenge arose in the communicating stage in which the teachers lead the students to develop their skills to offer or demonstrate all knowledge and ability that had been mastered verbally or nonverbally in the previous stage (Ratnaningsih, 2017). Communicating was also called collaborative learning in which the teachers' function tended to be more directive oriented (Suharyadi, 2013). However, the fact was that only little number of students was active while the rest were passive, afraid or not confident. The reason was that they were afraid to make incorrect of their sentences. The teachers' challenge was then make them motivated and not afraid to make mistakes.

The last challenge in the main activity was the teachers difficulty in organizing the steps of Scientific Approach in the sequence way. They thought that the stages should be adjusted with kind of materials being learnt, students condition and time management. The teachers were not demanded to arrange the main activities to be in sequence from observing to communicating. Furthermore, the teachers' creativity in designing the activities which reflected those three activities was very important to be considered in implementing this 2013 Curriculum.

Referring to all findings in this study, the challenges faced by the Vocational High School of Agriculture English teachers in implementing scientific approach related to the students' lack of motivation to learn, students' lack of selfconfidence, students' various intake and background, students' lack of vocabulary mastery and the difficulty in applying all stages of scientific approach in sequence.

\section{The Vocational High School English Teachers' Challenges in the Learning Assessment}

Referring to the finding in the learning assessment, the teachers' challenge was the difficulty to cover all aspects of authentic assessment in the 2013 Curriculum. As the techniques of authentic assessment proposed by Sani (2014), behavior competence could be assessed through observation, self-assessment, peer evaluation and journal. Meanwhile, knowledge competence could be assessed through written test, oral test and tasks. For assessing the skill competence, the teacher could use performance based test, projects and portfolios. However, the students' condition and limited time were the contributed factors that make the English teachers difficult to cover all aspects of authentic assessment in the area of students' knowledge and skill.

Those findings were in line with a study by Nur \& Madkur (2014) which revealed that authentic assessment was very demanding for the English teachers. Most of teachers argued that the scoring criteria were complicated and very time consuming. Moreover, a study by Retnawati et al., (2016) revealed the teachers' lack of comprehension understanding in implementing the learning assessment based on 2013 Curriculum including planning, conducting and reporting the result of students' achievements. The teachers' difficulties were also found in developing the instrument of attitude, implementing the authentic assessment, formulating the indicators, designing the assessment rubric for the skills, and gathering the scores from multiple measurement techniques. Similarly, Ekawati (2017) in her study also revealed the teachers' problems related to their lack of understanding in conducting evaluation. The result of her study showed that the teachers' difficulties were in arranging evaluation. They needed long time to input the score of four aspects in the authentic assessment since the classes were quite large. They also got difficulties in making an individual assessment or pair assessment and affective assessment. As the conclusion, the English teachers' difficulty to cover and applying all aspects of authentic assessment due to students' condition and limited time in this present study completed other challenges in the learning assessment during 2013 Curriculum implementation.

\section{The Vocational High School English Teachers' Challenges in the Classroom Management Practice}

Generally, the classroom management practice had been conducted by the teachers was also in accordance with the items in the regulation of the Permendikbud No. 22/2016 tentang Standar Proses Pendidikan Dasar dan Menengah. Referring the 2013 Curriculum demands, this regulation required the teachers to conduct a number of steps to be implemented including: (1) having to adjust the volume and tone of their voices, (2) having to speak politely, clearly and be easy to understand by their students, (3) having to dress modestly, be clean, and tidy, (4) having to organize the seating, (5) having to encourage and reward students to ask and argue, (6) having to create order, discipline, convenience, and safety for the teaching-learning processes, (7) having to provide reinforcement and feedback in response to students questions and return students' assignments and give out results whilst the learning process takes place, (8) having to adjust the speed of the subject matter to the ability of their students to learn, (9) having to explain to the students about syllabus for each of subjects at the beginning of each semester, and (10) having to begin and end the teaching-learning processes according to the term schedule.

Although the teachers had tried to implement all those steps as the curriculum demands, they got challenges in adjusting the seating arrangement with the learning activity since they considered more time to spend, less spacious classroom and the low quality of students' chairs and tables. The challenge also appeared in encouraging the students to ask and argue or give their opinion due to the difference of students' intake, therefore there was just less number of students who wanted to be active to ask and argue while the rest were passive. The last challenges experienced by the teachers was in adjusting the subject matter with the speed and ability of students to learn since there was a gap for high ability and low ability students.

The teachers' challenges in the classroom management practice during the implementation of 2013 Curriculum in this study were in line with a study by Habibi et al. (2017) about implementation of classroom management by English teachers at high schools in Jambi. Their study revealed that time-consuming was one of the problems in the seating arrangements 
experienced by the teachers among other problems such as big number of students in the classroom and small size of the classroom to move the chairs and tables around. In term of encouraging the students to ask and argue, this study also revealed that the problem dealt with the extra efforts and time needed by the teachers to do this step since most of students did not have self-confidence to tell what they want to say while some others tended to dominate this session.

\section{Practice of Professional Development Strategies by Vocational High School English Teachers in the 2013 Curriculum Implementation}

Referring to the challenges experienced by English teacher in conducting the professional development strategies during 2013 Curriculum implementation, the focus seemed on the teachers and principals involvement. The teachers were as the executors who conduct the professional development strategies while the principals were as the facilitators who support the teachers to implement those strategies.

As the findings presented in the previous part, the first challenge was that the principals had actually supported the teachers to do peer-coaching and team teaching, however, the teachers still faced difficulty to implement since they could not match their time with their partner. Thus, there was lack of communication, cooperation or collaboration between the teachers in their teaching practice. It was in line with the study by Hismanoglu (2010) which implied that lack of collaboration was a fundamental barrier in the teachers' professional development because the strategies requiring communication and collaboration were preferred at very low rate.

Meanwhile, as supports, feedback and assistance the teachers got from their partners in peer-coaching, Sutjipto (2007) in his study revealed that peer-coaching could be beneficial for the teachers in terms of reducing isolated feeling among the teachers, increasing the skill for implementing the teaching strategy effectively and creating the climate school to be more positive. In line with Sutjipto, Thorn et al. (2007) explained that peer-coaching could help the teachers to develop their personal development plan, establish collaborative norms, build a shared knowledge base, enable them to give and receive ideas, share successful practices, encourage reflective practice, etc. In term of team teaching, Buckley (2000) emphasized that it included the teachers in group to work together in a purposeful, regular, and cooperative fashion in teaching a group of students. Thus, it led more interaction between the teachers since they together had to set goals for a course, design a syllabus, prepare individual lesson plans, teach students and evaluate the results. Therefore, related to the challenges in peer-coaching and team teaching, the teachers' communication and collaboration might necessarily be increased and facilitated by the principals.

The second challenges dealt with lack of financial support for the English teachers to participate in the study group activity as the English Teachers Forum (MGMP). English teacher's forum was a program to develop innovation, creativity, communication, consultation, information, and coordination among English teachers to increase the teaching quality. Hence, related to the lack of financial support, it needs the principals' attention and decision to allocate more budgets for the teachers to participate in this forum.

The third challenge concerned on the teachers' less participation in the in-service training activity since sometimes it was difficulty for them to get the information access about seminars or training that could increase their knowledge and ability in teaching as the 2013 Curriculum demands. Meanwhile, a study by Wardhana (2016) revealed that training for the teachers had effective influence to the 2013 Curriculum implementation in the Vocational High School in Yogyakarta even though it's contribution was only $3,79 \%$. Therefore, it needs more supports from the school to give as much as possible information for all teachers related to the workshops, seminars or training in the area of 2013 Curriculum implementation to increase the English teachers' participation in developing their professionalism.

\section{Limitation of the Study}

Limitation in this study related to the schedule of the research and the criteria of the research subjects. The researcher could conduct the research in the even semester. At that time, the schools had no adequate schedule of classoom teaching practice since there were a lot of activities such as UN, registration of new students, fasting preparation, and others. As the result, the classoom observation could effectively be conducted once for each English teacher. In terms of criteria of research subject, it should involve the research subjects who have the same background of their education. However, one of English teachers has no relevant education background since she had to replace one of English teacher who has resigned from the school in few years ago. Due to this fact, the school has decided to appoint one of their teachers who has the highest score of Toefl and Toeic to teach English although she has not graduated from ELT.

\section{CONCLUSION}

Referring to the findings, it could be concluded that English teachers at Vocational High School of Agriculture in South Kalimantan faced a number of challenges in the 2013 Curriculum implementation. In the lesson planning, the challenges dealt with the teachers' difficulties in reviewing syllabus, deciding indicators and determining kind of assessment. Meanwhile, the challenges in the lesson implementation appeared in preparing and motivating the students to learn and in applying the Scientific Approach. In the learning assessment, the challenge was concerned on the difficulty to cover all aspects of authentic assessment, especially in assessing students' knowledge and skill. Dealing with classroom management practice, the teachers 
also faced the challenges in terms of adjustment of seating arrangement, encouragement the students to ask and argue or give their opinion and adjustment of the subject matter with the speed and ability of students to learn.

The most of strategies had been conducted by English teachers in the professional development were teaching portfolio, in-service training, and study group. Meanwhile, they were rarely or never conducted other strategies such as peercoaching, mentoring, team teaching and action research. During the 2013 Curriculum implementation, the challenges also appeared in the professional development strategies practice such as lack of communication, cooperation or collaboration between the teachers to conduct peer-coaching and team teaching, lack of financial support for the English teachers to participate in the study group activity as the English Teachers Forum (MGMP) and difficulty to get information access about seminars or trainings.

Some suggestions are addressed for the stakeholders and the future researchers. Firstly, the researcher suggests stakeholders to give concerns on the constraints during the implementation of 2013 Curriculum. Since there were many kinds of socialization, workshops, seminars or trainings about this curriculum that have been conducted, the government needs to evaluate the effectiveness of those programs, especially how they give better impacts toward the English teachers in implementing the 2013 Curriculum. For the principals, it is necessary to increase the supervision and coaching to the English teachers concerning on the process of designing lesson plan, teaching practice, learning assessment and classroom management practice. Moreover, they need to give more supports to the teachers in developing their professionalism in terms of financial supports and information access to increase the teachers' participation in the MGMP forum and many kinds of in-service training programs. Another suggestion is addressed to the future researchers who are interested in the area of 2013 Curriculum implementation. Since there was limited number of classroom observation in this study due to the school schedule, the researcher suggests that they conduct the similar study with more frequency of classroom observation, more relevant subjects and area coverage. Thus, the more comprehensive data related to the implementation of the 2013 curriculum can be revealed.

\section{REFERENCES}

Ahmad, D. (2014). Understanding the 2013 Curriculum of English Teaching through the Teachers' and Policymakers' Perspectives. 2(4), 6-15.

Albana, H. H. (2016, June 30). English Teachers' Perspective on The Implementation of 2013 Curriculum (A Case Study at SMP 3 South Tangerang in Academic Year 2015/2016).

Anni, C. T., \& Rifa'i, A. (2009). Psikologi Pendidikan. Semarang: UNNES.

Brown, H. D. (2000). Principles of Language Learning and Teaching (Fourth). New York: Longman.

Buckley, F. J. (2000). Team Teaching: What, Why, and How? San Fransisco: Longman.

Checkovich, B. H., \& Sterling, D. R. (2001). Oh Say Can You See. Science and Children, 38(4), 32-35.

Cohen, L., Manion, L., \& Morrison, K. (2007). Research Method in Education (Sixth Edition). London: Routledge.

Creswell, J. W. (2012). Educational Research: Planning, Conducting, and Evaluating Quantitative and Qualitative Research (4th Edition). Boston: Pearson Education, Inc.

Ekawati, Y. N. (2017). English Teachers' Problems in Applying The 2013 Curriculum. English Review: Journal of English Education, 6(1), 41-48. https://doi.org/10.25134/erjee.v6i1.769

Febry, A. I. H. (2017). The Implementation of Assessment Based on The 2013 English Curriculum in Senior High Schools in Malang. Universitas Negeri Malang, Malang.

Firdaus, R. (2016). English Teachers' Perception on the Implementation of the 2013 English Curriculum and KTSP: Difficulties and Differences (A Case Study at One of the Senior High School in Margahayu) [E-Portfolio]. Retrieved from Universitas Pendidikan Indonesia website: http://rezkifirdaussps.blogspot.com/2016/01/english-teachers-perceptionon.html

Gopalan, V., Bakar, J. A. A., Zulkifli, A. N., Alwi, A., \& Mat, R. C. (2017). A Review of The Motivation Theories in Learning. 020043-1-020043-020047. https://doi.org/10.1063/1.5005376

Habibi, A., Mukminin, A., Sofwan, M., \& Sulistiyo, U. (2017). Implementation of Classroom Management by English Teachers at High Schools in Jambi, Indonesia. Studies in English Language and Education, 4(2), 172-189. https://doi.org/10.24815/siele.v4i2.6104

Hasan, A., Gushendra, R., \& Yonantha, F. (2017). The Influence of Prior Knowledge on Students' Listening and Reading Comprehension. IJEE Indonesian Journal of English Education, 4(1), 1-15. https://doi.org/10.15408/ijee.v4i1.4744

Hismanoglu, M. (2010). Effective professional development strategies of English language teachers. Procedia - Social and Behavioral Sciences, 2(2), 990-995. https://doi.org/10.1016/j.sbspro.2010.03.139

Hutchinson, T., \& Waters, A. (1987). English for Specific Purposes: A Learning-Centered Approach. Cambridge: Cambridge University Press.

Irawati, C. (2016). The Vocational High School (VHS) Teacher's Perceptions on 2013 Curriculum English Materials: A Case Study at SMKN 7 Malang. Universitas Negeri Malang, Malang.

Khasanah, I. N. (2015). The Implementation of 2013 Curriculum by The English Teacher and Its Barriers (A Case Study at the 10th Grade of SMA N 1 Rembang in 2014/2015 Academic Year). Walisongo State Islamic University, Semarang. 
Lambert, V. A., \& Lambert, C. E. (2012). Qualitative Descriptive Research: An Acceptable Design. Pacific Rim International Journal of Nursing Research, 16(4), 255-256.

Lampiran III Peraturan Menteri Pendidikan dan Kebudayaan Nomor 34 Tahun 2018 tentang Standar Proses Pembelajaran SMK/MAK. (2018).

Lampiran Peraturan Menteri Pendidikan dan Kebudayaan Nomor 22 Tahun 2016 tentang Standar Proses Pendidikan Dasar dan Menengah. (n.d.).

Menteri Pendidikan Nasional. (2007). Standar Proses untuk Satuan Pendidikan Dasar dan Menengah. Jakarta: BSNP.

Menteri Pendidikan Nasional. (2013). Pengembangan Kurikulum 2013. Retrieved from http://kurikulum.kemdikbud.go.id

Merriam, S. B. (2009). Qualitative Research: A Guide to Design and Implementation. San Fransisco: John Wiley \& Sons.

Mulyasa, H. E. (2017). Pengembangan dan Implementasi Kurikulum 2013. Bandung: Remaja Rosdakarya.

Napratilora, M., Kurniawan, N. A., \& Siagian, S. Y. (2019). English Teacher Obstacle on Implementing the 2013 Curriculum. Indonesian Journal of Learning Education and Counseling, 1(2), 119-123. https://doi.org/10.31960/ijolec.v1i2.91

Noviawati, N. (2017). The Implementation of 2013 Curriculum in English Teaching Learning at MAN 1 Pekalongan. IJET, 6(2), $218-228$.

Nur, M. R., \& Madkur, A. (2014). Teachers' Voices on The 2013 Curriculum for English Instructional Activities. IJEE (Indonesian Journal of English Education), 1(2), 119-134. https://doi.org/10.15408/ijee.v1i2.1340

Patton, M. Q. (1999). Enhancing the Quality and Credibility of Qualitative Analysis. HSR: Health Services Research, 34(5), 1189-1208.

Peraturan Menteri Pendidikan dan Kebudayaan Nomor 70 tahun 2013 tentang Kerangka Dasar dan Struktur Kurikulum SMK/MAK. (2013).

Ratnaningsih, S. (2017). Scientific Approach of 2013 Curriculum: Teachers Implementation in English Language Teaching. English Review: Journal of English Education, 6(1), 33-40. https://doi.org/10.25134/erjee.v6i1.768

Retnawati, H., Hadi, S., \& Nugraha, A. C. (2016). Vocational High School Teachers' Difficulties in Implementing the Assessment in Curriculum 2013 in Yogyakarta Province of Indonesia. International Journal of Instruction, 9(1), 33-48. https://doi.org/10.12973/iji.2016.914a

Rusmono. (2018, February 14). Semua SMK-PP Harus Kerjasama Dengan Pelaku Dunia Usaha dan Dunia Industri. Pilar Pertanian. Retrieved from https://pilarpertanian.com/semua-smk-pp-harus-kerjasama-dengan-pelaku-dunia-usaha-dandunia-industri

Sani, R. A. (2014). Pembelajaran Saintifik untuk Implementasi Kurikulum 2013. Jakarta: Bumi Aksara.

Setyawan, I. K. A. (2012). A Complexity Correlative Analysis, Supporting Capacity, and Student' Intake towards Their Biology Learning Achievement at the Junior High Scholl (SMP) around Badung Regency. Jurnal Penelitian dan Evaluasi Pendidikan, 2(1), 1-12.

Sharafi-Nejad, M., Raftari, S., Bijami, M., Khavari, Z., Ismail, S. A. M. M., \& Siew Eng, L. (2014). The Impact of Vocabulary Enhancement Activities on Vocabulary Acquisition and Retention among Male and Female EFL Learners in Iran. English Language Teaching, 7(4), p126. https://doi.org/10.5539/elt.v7n4p126

Suharyadi. (2013). Exploring Scientific Approach in English Language Teaching. Malang: Universitas Negeri Malang.

Sutjipto. (2007). Peer-Coaching sebagai Wahana Guru untuk Berkolaborasi Melalui Teknologi Informasi dan Komunikasi. Jurnal Pendidikan dan Kebudayaan, 13(65), 206-228.

Thorn, A., McLeod, M., \& Goldsmith, M. (2007). Peer Coaching Overview. Retrieved from http://www.marshallgoldsmithfeedforward.com/docs/Peer-Coaching-Overview.pdf

Undang-Undang Republik Indonesia Nomor 20 Tahun 2003 tentang Sistem Pendidikan Nasional. (2003). Retrieved from http://kelembagaan.ristekdikti.go.id/wp-content/uploads/2016/08/UU_no_20_th_2003.pdf

Wardhana, R. A. N. (2016). Pengaruh Kepemimpinan Kepala Sekolah, Profesionalisme dan Pelatihan Guru Terhadap Implementasi Kurikulum 2013 SMKN Yogyakarta. Jurnal Akuntabilitas Manajemen Pendidikan, 4(2), $257-269$. https://doi.org/10.21831/amp.v4i2.10812

Widiati, U., Suryati, N., \& Hayati, N. (2018). Unraveling the Challenges of Indonesian Novice Teachers of English. Indonesian Journal of Applied Linguistics, 7(3), 621-629. https://doi.org/10.17509/ijal.v7i3.9824

Yusuf, A. O. (2018). Senior High School English Teachers' Knowledge, Beliefs and Implementation of Scientific Approach of Curriculum 2013 in Banjar Regency South Kalimantan. Universitas Negeri Malang, Malang. 